Scheerder, J., Willem, A., Claes, E., \& Billiet, S. (2015). The position and power of national sports (con) federations-Agency relationship or co-governance? 12th European Association for Sociology of Sport Conference, Dublin, 10-13 June.

Spanish Parliament. (1990). Sports Act 10/1990 of 15 October. http://www. csd.gob.es/csd/informacion-en/legislacion-basica/ley-del-deportel (retrieved 14 September 2015).

Subirats, J. (1999). ¿Existe sociedad civil en España? Responsabilidades colectivas y valores públicòs. Madrid: Fundación Encuentro.

The World Bank. (2013a). Land area. http://data.worldbank.org/indicator/ AG.LND.TOTL.K2 (retrieved 15 September 2015).

The World Bank. (2013b). Urban population. http://data.worldbank.org/indicator/SP.URB.TOTL.IN.ZS (retrieved 16 September 2015)

Tokarski, W., Petry, K., Groll, M., \& Mittag, J. (2009). A perfect match? Sport in the European Union. Maidenhead: Meyer \& Meyer (UK)

\section{Switzerland: The Organisation of Sport and Policy Towards Sport Federations}

\author{
Emmanuel Bayle
}

1

\section{Introduction}

This chapter examines the relationship between government and sport federations in Switzerland. This relationship is not subject to national public regulation, as in many other countries, and the independent nature of the Swiss Olympic Committee (Swiss Olympic) and national sport federations means that the federal government's role is more to support and promote sport than to administer sport. Nevertheless, the federal government has a clear and incentivising national policy involving a modest amount of direct public finance, although the sums invested in sport have grown substantially over the last ten years. In addition, the system for funding elite sport has recently been revamped through the introduction of service contracts with sport federations, supervised by Swiss Olympic.

E. Bayle (范)

Institute of Sport Sciences, University of Lausannc, Lausanne, Switzerland

(C) The Author(s) 2017

J. Scheerder et al. (eds.), Sport Policy Systems and Sport Federations, 


\section{Country Profile}

Switzerland is divided into 26 cantons and 2396 municipalities. It is a mountainous country consisting of part of the Alps, the Central Plateau and part of the Jura. Two-thirds of the population is urban, with a third living in the five largest cities. The country's overall population density is low, at just 201 people per square $\mathrm{km}$. Switzerland, or more accurately the Swiss Confederation, has four official languages: French, German, Italian and Romansh. Switzerland draws its identity from a shared history and its federal tradition. Two significant features differentiate Switzerland from other countries:

- Its system of direct democracy, which allows citizens to use "popular initiatives", referenda and other mechanisms to "directly" influence the political process.

- Its federal system, which divides policy areas between three levels of government: the confederation, the cantons (26) and the municipalities (Table 1).

Table 1 Facts and descriptives of Switzerland

\begin{tabular}{ll}
\hline Number of inhabitants* & $8,237,000$ \\
Surface (in $\mathrm{km}^{2}$ ) & 39,516 \\
Population density (inhabitants/km²) & 201.3 \\
Urban population (\%) & 74 \\
Average age of population (in years)* & 39.77 \\
Population with migrant background & 24.3 \\
$(\%)^{*}$ & \\
Political organisation & Parliamentary constitutional republic \\
Structure of the state & Federal \\
Number of cantons & 26 \\
Number of municipalities* & 2,396 \\
GDP per capita (US dollars)** & 84,815 \\
Number of official languages & 4 \\
EU membership & No \\
Welfare model & Rhineland \\
\hline Sources: $\star$ Swiss Statistics (2015)***OECD. &
\end{tabular}

Sources: *Swiss Statistics (2015); **OECD.

\section{Sport in Switzerland}

According to Chappelet and Mrkonjic (2011), at the end of the nineteenth century it became the army's responsibility to encourage sport in Switzerland. Under the 1874 Army Act, schools had to provide gymnastics lessons in order to prepare young men for military service, but it was not until the 1960s that the government began to promote the positive effects of sport on health and education. Without downplaying its contribution to the country's defence, sport was now seen as an important factor in boosting personal well-being. It was also a question of ensuring Switzerland performed honourably in international competitions. Public health and education remained the responsibility of the cantons. As a result of this sporting history and 40 years of government policy in favour of sport, Switzerland is a very sporty country. In fact, 44 per cent of people between the ages of 15 and 74 claim to do some sort of sports activity several times per week (cf. 3.1), around 25 per cent do sport at least once a week and a further 5 per cent do sport occasionally or rarely. The remaining 26 per cent describe themselves as non-sporty. For many Swiss, sport is mostly an outdoor activity (hiking, mountaineering, swimming, cycling) and is often done outside any formal structure. Nevertheless, most sport is done within clubs (25 per cent of the population), OFSPO (2011a realised by Lamprecht et al.) and this is particularly the case for young men and seniors. Friendship, conviviality, regular sessions and high-quality coaching are cited as the main advantages of doing sport with a club. Approximately 7 per cent of Swiss people help out as volunteers in clubs, that is almost 285,000 people, equivalent to 21,000 full-time staff and CHF 2 billion in saved costs. This compares with the clubs' 17,500 salaried staff, equivalent to 5300 full-time posts (OFSPO Club Study, 2011a). Hence, volunteers are a vital component of Switzerland's federal sports system. Fitness centres, which have 14 per cent of the population as members, also play an important role (Lamprecht, 2014). Asked to state the main attractions of fitness centres, users cited their flexibility, the ease of using them and their long opening hours. Unlike sports clubs, the majority of whose members are men, the majority of fitness centre members are women, who are attracted by the variety of the offers fitness centres propose. The study also found that people in the German-speaking parts of Switzerland are sportier than 
those in either the Italian- or the French-speaking parts (although OFSPO's latest study, carried out in 2014, showed that participation levels among French-speakers had caught up with German-speakers). Football, downhill skiing, tennis and ice hockey are the most popular sports. Only two team sports, football and ice hockey, are truly professional in Switzerland, and ice hockey plays a major role in local culture and identity.

Sport contributes 1.7 per cent of the country's GDP and provides 2.5 per cent of jobs (OFSPO, 2014). These figures are higher than in most other western countries due to the presence in Switzerland of around 70 international sport organisations (including the head offices of the IOC, FIFA and UEFA, each of which employs around 500 permanent staff), which earn the country more than CHF 1 billion every year (Rutter \& Partner, 2013), and the importance of sports tourism, especially skiing (24 per cent of created value and one-third of jobs). However, the production of sports equipment and clothing contributes much less to Switzerland's economy than it does in France or North America, for example. Thirty per cent of jobs in Switzerland's sports sector are provided by the country's 27,000 sports facilities and 16 per cent are provided by fitness clubs.

In 2014, the Swiss spent CHF 17.5 billion on sport (OFSPO, 2014), that is, an annial sports budget of CHF 2500 per person. A quarter of this money is spent abroad (OFSPO, 2014) (Table 2).

\section{Organisation of Sport}

\subsection{Structure}

The scheme in Fig. 1 presents an organisation of the structure of the sports system in Switzerland. Regarding this scheme, we explain the role of the main actors in the sport national system.

\section{Governmental Actors}

Under Article 68, paragraph 1 of the Swiss Constitution, the Confederation shares responsibility for promoting sport with the cantons and the municipalities. The present chapter focuses uniquely on federal sports policy,
Table 2 Sports profile of Switzerland

Government authority responsible for sport Sports club membership (\%)*

Fitness or well-being centre membership (\%)*

Sports participation, at least once a week (\%)*

Number of national sports federations ${ }^{a}$

Number of sports clubs

Number of sports club members

Average number of members per club

National budget for sport (CHF)

National budget for sport federations (CHF)

Local budget for sport (CHF)

Federal Department of Defence, ivil Protection and Sport

25

16

$25 \%$

86

20,700

$1,600,000$

77

1.2 billion (around 120 million by the State)

150 million

1 billion for municipalities and 130 million for the cantons)

Economic contribution of volunteers in sport as a percentage of GDP $(\%)^{* *}$

0.30

Sources: *European Commission (2014); ${ }^{*} \mathrm{GHK}$.

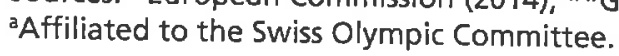

and therefore the national government's expenditure on sport, without examining the contributions of the cantons and municipalities. This decision was made for two reasons. First, the cantons' sports policies follow those of the national government, as it is the cantons that implement federal policy. Second, although Switzerland's municipalities spend eight times as much on sport as the national government, municipal sports policies vary so widely it would be impossible to describe them all.

Policies drawn up by the Federal Department of Defence, Civil Protection and Sport (DDPS) are put into effect by the Federal Office for Sport (OFSPO), which was set up in 1999 to implement Switzerland's sports policy. In 2000, OFSPO drew up a strategy document entitled the "Concept of the Federal Council for a Sports Policy in Switzerland" (CCFPSS). This document outlined five strategic objectives for developing sport: (1) to increase the percentage of the population who regularly take part in physical activity (health); (2) to use the possibilities provided by sport for education (education); (3) to support young talent and elite sport (performance); (4) to make use of sports' economic potential 


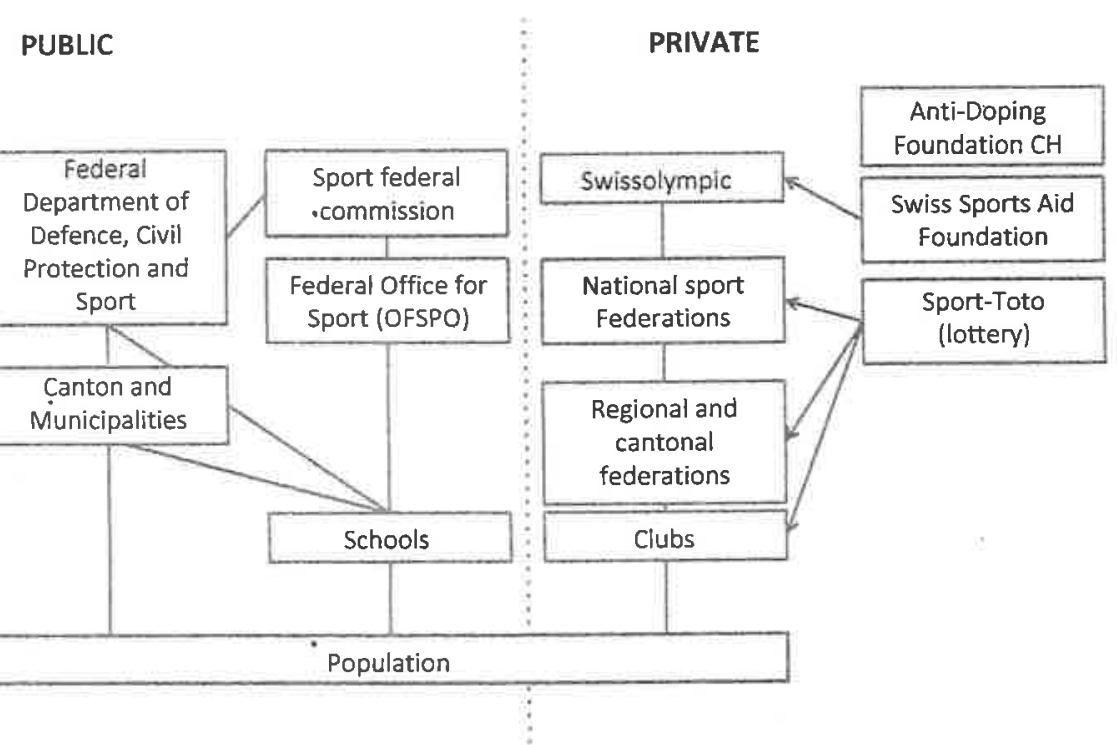

Fig. 1 Organisation of sport in Switzerland ( $>$ Financing system for the private side)

(economy); and (5) to make sport a training ground for the sustainable development of society (sustainable development).

OFSPO runs two training centres for elite sport, at Magglingen and at Tenero, which provide scientific monitoring and training facilities for elite sportspeople and courses for the training of coaches. The Swiss Federal Institute of Sports Magglingen (HEFSM) provides training courses for universities, federations, associations, clubs and schools.

Two programmes specifically target young people:

- "School moves" encourages students to do at least 20 minutes physical activity every day, in addition to their PE lessons (Lamprecht et al., 2014).

- "Youth + Sport" $(J+S)$ is OFSPO's main programme for encouraging sport. Its courses and camps for children and teenagers cover 75 different sports. Every year, around 550,000 young people take part in this flagship programme (Lamprecht, Fischer, \& Stamm, 2011a), which provides 55,000 courses and camps with places for up to 700,000 people between the ages of 5 and 20 . Set up 40 years ago, $J+S$ involves more than 65,000 instructors (12,000 new instructors every year), 9000 coaches and 3000 experts who run more than 3000 training and continuing training modules every year (Lamprecht et al. 2014). This programme, which is of great benefit to sport federations and clubs, costs the Confederation around CHF 80 million per year. The cantons, through their $\mathrm{J}+\mathrm{S}$ departments, are $\mathrm{J}+\mathrm{S}$ 's closest partners. They perform a variety of tasks with respect to training managers, administering training courses for young people and ensuring rules are followed. The federations provide specialists in developing their sport and run $\mathrm{J}+\mathrm{S}$ approved initial-training and further-training modules. Sports clubs have developed longstanding offers suited to different age groups and use $\mathrm{J}+\mathrm{S}$ subsidies to encourage young people to do sport (Jeunesse + Sport, 2014).

In addition, OFSPO has projects focusing on the fight against doping and violence in sport. With respect to violence, OFSPO works in conjunction with the Federal Office of Police and uses the following two instruments to fight hooliganism:

- The HOOGAN electronic database of hooligans.

- Preventive measures (bans from approaching or entering sports grounds, bans from visiting a given country, obligation to report to a police station, preventive custody).

\section{Non-Governmental Actors}

Swiss Olympic is both the National Olympic Committee and the umbrella organisation representing Swiss federations for both Olympic and nonOlympic sports. It was created on 1 January 1997, when the Swiss Sports Association (ASS) merged with the Swiss Olympic Committee (COS) and simultaneously integrated the National Committee for Elite Sport (CNSE) (Lamprecht et al. 2014). Hence, Swiss Olympic is both Switzerland's Olympic committee and the national governing body for 
sport. It has three main strategic missions: to strengthen the federations; to promote ethics; and to carry out Olympic missions (participation in the Olympic Games).

Swiss Olympic is the umbrella organisation for 86 sports federations with 1.6 million members (including people who are members of more than one federation) in 20,700 clubs (OFSPO, 2014). The larger federations are divided into regional (3) and cantonal (26) associations. Most are single-sport federations, but there are also a small number of multi-sport federations, such as the Swiss Non-Commissioned Officers Federation.

Given the size of their membership, the 20,700 sports clubs play an essential role in the country's sporting life (point 3; see also Lamprecht et al., 2011a, 2014). Most clubs are run by unpaid staff and therefore rely on their 300,000 volunteers (considered as such if they are paid less than CHF 2000 per annum).

\section{Intermediate Actors}

The main body responsible for the fight against doping is a foundation called Antidoping Switzerland, which is co-financed by the Confederation and Swiss Olympic (Antidoping, 2014).

In recent years, the way in which Swiss sport is organised has evolved significantly. Sport was essentially a private matter up until 1970. Since then a number of developments, including the 1972 Sports Act and, most importantly, the creation of OFSPO in 1999, have greatly increased the level of government participation in sport. This has resulted in the introduction of a federal policy for sport, whose structure is based on the principle of subsidiarity. The cantons and municipalities are very important in implementing this sports policy, although the cantons rule supreme with respect to sport and have their own specific laws. On the other hand, elite sport is run by Swiss Olympic.

The government plays a motivational role in sport, notably with respect to sport for all and especially since the Act of 17 July 2011, which defines the areas in which the Confederation can support or finance sport directly. Principal-agent theory provides a useful framework for analysing the relationship between Swiss Olympic and OFSPO, with the government as the principal and sports (con)federations as agents.

\subsection{Steering}

In line with Henry and Ko (2009) and Vocasport (2004), the Swiss government believes that leaving the control of sport to those with expertise and commitment, the associated externalities will follow. This means that the country's sports policy can be classified as having a missionary configuration. Under Swiss law, the Confederation's role is to drive/stimulate sports policy but not to directly set elite sport policy, which is decided by negotiations between Swiss Olympic and the sport federations.

\section{Legislative Framework}

Switzerland first introduced specific sports legislation in 1972. This legislation, which was reviewed in 2011, sets out the Confederation's areas of competence. The following section is based on research by Chappelet and Mrkonjic (2011).

Switzerland's first federal law to encourage gymnastics and sport (LEGs) came into force in July 1972. It laid down rules for compulsory physical education at school (three hours per week), the support given to different sports organisations, the subsidies available for building gymnasiums and sports centres, and the financial support available for research in the sports sciences. The biggest change brought in by this law was the organisation of the "Youth and Sport" $(J+S)$ programme for young people between the ages of 14 and 20 , which receives substantial levels of government funding. During the 1980 s and 1990 s, no fewer than eight sports-related government orders came into force, the most important of which concerned the organisation of the $J+S$ programme (1980), the promotion of gymnastics and sport (1988) and the government's tasks. Other orders addressed the training of physical education teachers for schools and universities (1988), the granting of subsidies to the Olympic association and national sport federations (1989), allowances for advance 
sports courses (1992) and sports services for seniors provided by the Confederation (1999).

On 17 July 2011 a new sports act was enacted, the Federal Law to Encourage Sport and Physical Activity (LESp). The main modifications concerned the extension of the $J+S$ programme to children as young as five years old (with the same upper age limit of 20 years), the provision of extra support for competitive sport (through subsidising the training of coaches), the strengthening of penal sanctions for doping by athletes and the creation of a legal framework for exchanging data between national and international anti-doping bodies. Other clauses in the LESp were designed to make the financial aid attributed to sport federations and organisations even more dependent on their actions to promote sporting ethics and to efficiently manage the attribution of resources to promote sport.

\section{Policy Framework}

The model underlying the organisation of sport in Switzerland is based on two main principles: the independence of Switzerland's Olympic Committee (Swiss Olympic) and national sport federations from the State and the "federalised implementation" of sports policies (Chappelet \& Mrkonjic, 2011)—a consequence of Switzerland's federal structure. Although there is substantial direct and indirect public investment in sport on a local level, the national government's contribution is targeted quite narrowly through two national sports schools (most importantly, Magglingen, Switzerland's top centre for elite sport), its flagship "Youth + Sport" programme, the construction and renovation of nationally important sports facilities and support for the hosting of international sports events. Support for the professionalisation of national sport federations is more recent and is provided in the form of financial incentives paid via Swiss Olympic, which manages these sums through the establishment of performance contracts with the federations. In terms of the VOCASPORT typology, Switzerland's sport policy/organisation model can be categorised as an evolving missionary configuration, in which the sports movement has traditionally relied on volunteers and had great autonomy to make decisions, but which has recently seen a substantial increase in the levels of government regulation and financing (with the creation of a federal ministry for sport in 1999 and a fourfold increase in government expenditure on sport between 1972, when Switzerland's first federal sports act was passed, and 2011). Private enterprise is also an important part of Swiss sport, due to the size of the fitness industry and the fact that elite athletes do not have any official status, so they have no social security cover and receive little financial assistance from the State to help them train as truly "professional" athletes.

\subsection{Support}

\section{Financial Framework}

National Level

According to Chappelet and Mrkonjic (2011), the national government's spending on sport increased fourfold between 1970 and 2007, a period when the country's GDP less than doubled. Municipalities are still the main source of finance for developing sport in Switzerland, contributing around CHF 1 billion per year, according to official public figures (Chappelet \& Mrkonjic 2011). The national and cantonal governments contributed around CHF 200 million, but this figure has undoubtedly increased to almost CHF 300 million (half of which is provided by the national government). The government finances both elite sport and sport for all, providing around CHF 15 million for elite sport in 2013 (as direct finance and by financing the Magglingen centre) and transferring approximately CHF 80 million to sports clubs for the $J+S$ programme. A final CHF 25 million is available to finance national-level sports infrastructure and to host international events (interview with a Swiss Olympic executive). The 2000 s were notable for the preparations for the 2008 European Football Championships, hosted jointly by Switzerland and Austria. In 2002, during the bidding phase, the Federal Council set at CHF 3.5 million the government's contribution to organising what would be the largest event ever held in Switzerland. This money 
was to be spent on improving media facilities and safety at four stadiums (Bern, Basel, Zurich, Geneva), an advertising campaign to promote the benefits of sport on health and social integration, and policing to ensure security during the event. Acceptance of the bid resulted in the government greatly increasing its subsidy. Following a stormy debate in parliament, the Federal Council finally agreed to provide CHF 82.5 million, most of which was earmarked to ensure security on a federal level (CHF 25.2 million), to help the host cantons ( $\mathrm{CHF} 10.5$ million) and to form a reserve to provide extra security if needed (CHF 10 million, which was not used). Thus, half of this provisional subsidy was set aside for security (army and police); the rest was used to refurbish stadiums (CHF $10.8 \mathrm{mil}-$ lion), to promote Switzerland's attractiveness to businesses and tourists (CHF 10 million) and to finance projects to promote sport in Switzerland both before and after EURO 2008 (CHF 5 million). In addition to these sums, host cities and cantons invested around CHF 100 million, taking advantage of the favourable economic conditions at the time (just before the stock market crash in October 2008). In order to justify this expenditure, the government advertised the event's economic impact. A post-event study conducted in 2010 showed that the gross value added by EURO 2008 was CHF 1008 million, a substantial sum that added 0.18 per cent to Switzerland's GDP for that year (Universität Bern 2010).

Hence, Switzerland's national sport budget is mostly devoted to the Youth + Sport programme in order to supervise and develop youth sport. In addition, the Federal Council may also provide substantial subsidies to help host international sports events, especially for building and renovating sports facilities.

\section{Local Level}

Municipalities are the most important source of finance for Swiss sport, as they contribute massively to the construction, renovation and maintenance of sports facilities and also help clubs implement their sports policies by providing subsidies and guaranteeing their deficits. The cantons rarely provide financial assistance to clubs; their main role is to supervise the provision of sport in schools and to administer the Youth + Sport programme in relation with clubs.

\section{Other Sources of Finance: The Importance of the Lottery}

Games of chance form another important source of finance for Swiss sport. This market remains highly regulated in Switzerland with only Swisslos and Lottery of Romande are allowed to offer sports betting. However, they have to denote a proportion of their profits to sport. According to Sport Toto (equivalent of other countries' sports lotteries) divides this money between national funds (CHF 36.6 million in 2010) and cantonal funds (CHF 108 million in 2010) (see Table 3). It also manages a national sporting foundation (Swiss Sports Aid Foundation, $\mathrm{CHF} 1$ million) and a separate foundation in each canton. The federations responsible for the two most popular sports in Switzerland, ice hockey and football, which are open to regulated sports betting, receive

Table 3 Distribution of lottery funding for sport

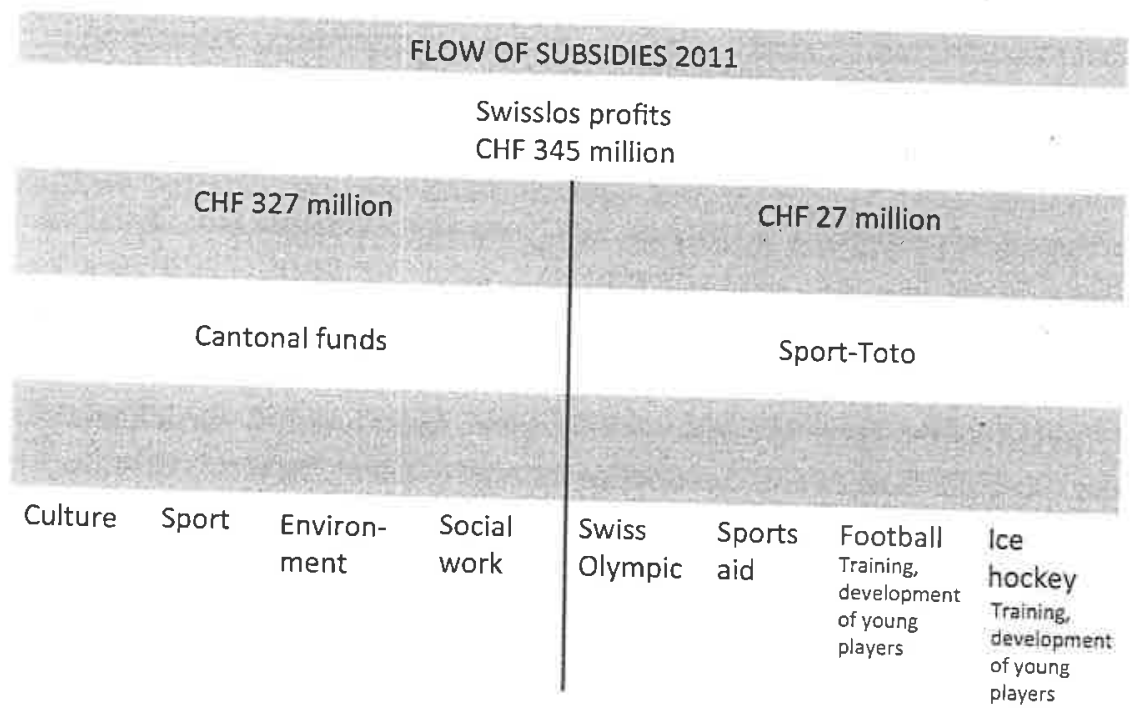


extra funding from the lotteries. This money (CHF 2.2 million for ice hockey, CHF 4.4 million for football) has to be spent on youth training. Sport Toto is also the largest contributor to Swiss Olympic (CHF 24.6 million), helping it to cover the cost of its 65 staff.

\section{Financial Support from Other Actors}

Swiss Olympic's budget for 2015 was CHF 45 million, most of which was provided by Sport Toto ( 55 per cent) and the government ( 22 per cent). Other notable sources of revenue include sponsors ( 6 per cent). As is common to most other European countries, alcohol and tobacco companies are not allowed to sponsor sport in Switzerland. Swiss Olympic distributes 42 per cent of its income to the national sport federations, 95 per cent of which goes to elite sport (around CHF 20 million, interview with $\mathrm{SO}$ ). The 86 federations ( 18 are not involved in competitions) manage 142 disciplines. Swiss Olympic classifies the federations into five categories on the basis of their size (number of members), media profile, economic importance and their actual and potential results in top-level competitions. The amount of money each federation receives depends on this classification. Since 2013, Swiss Olympic has signed four-year (the length of an Olympiad) service contracts in which the federations have to state their:

- overall strategy and their strategy for elite sport, ethics strategy (doping, corruption, violence, transparency, etc.);

- management report (annual accounts and business reports, without which they will not receive the sums allocated to them).

Each federation receives a base contribution depending on the number of its members (Table 3 provides figures for 2014). The most important criterion with respect to finance is elite sport, most notably, participation in the Olympic Games and developing emerging talent. In terms of subsidies linked to the organisation of major events, the government awarded the Swiss athletics federation, via service contracts managed by Swiss Olympic, an annual subsidy of CHF 600,000 from 2012 to 2014 for hosting the 2014 European Championships in Zurich. The Swiss ski federation (Swiss Ski)
Table 3 Criteria governing the distribution of subsidies to national federations via service contracts with Swiss Olympic (in 2014)

\begin{tabular}{lcc}
\hline Type of contribution & Per year & Providers of funding \\
\hline Base & approx. CHF & Confederation $100 \%$ \\
Major sports event & 1.5 million & \\
& approx. CHF & Confederation $85 \% /$ \\
New talent & 3.5 million & Sport-Toto $15 \%$ \\
& approx. CHF & Confederation $50 \% /$ \\
Elite & 5 million & Sport-Toto $50 \%$ \\
& approx. CHF & Sport-Toto $100 \%$ \\
Olympia & 10 million & \\
& approx. CHF & Sport-Toto $100 \%$ \\
Success bonuses & 2 million & \\
& approx. CHF & Sport-Toto 100 \% \\
Compensatory payments & 0.125 million & \\
& approx. CHF & Sport-Toto 100\% \\
Olympic games/Paralympic games/ & 0.25 million & \\
Youth Olympic games/Universiades/ & 1.5 million & Sport-Toto $100 \%$ \\
World games & & \\
Source: Swiss Olympic. & &
\end{tabular}

received CHF 800,000 for organising the 2017 World Ski Championships at Saint-Moritz. These subsidies are designed to help Swiss teams take part in and achieve honourable results at sports events held in Switzerland.

As a result of applying these criteria, the Olympic federations receive 85 per cent of the subsidies, with 58 per cent going to Summer Olympic sports and 27 per cent going to Winter Olympic sports, even though the five winter sport federations won 60 per cent of Olympic medals and diplomas at games between 1994 and 2014. Each federation receives at least CHF 2000 per year, although the subsidies can be as high as CHF 4.9 million. This system marks a new way, based on results and performance, of regulating and justifying the public money distributed by Swiss Olympic. It also explains the growing professionalisation of Switzerland's sport federations (Lamprecht, Fischer, \& Stamm, 2011b), which had 1300 employees in 2012 (an increase of 120 over the past six years). These subsidies help finance posts such as national technical director, head of elite sport and head of upcoming talent, and help pay for the training of coaches, mostly oriented towards elite sport. 


\section{Governance and Management Support}

As a consequence of the legislative, policy and financial frameworks described above, there is no direct link between the government administration of sport and the elite sport federations. In fact, the federations' goals are defined by Swiss Olympic in partnership with the federations, rather than by the government. Nevertheless, the federations continue to receive most of their finance from the lottery and the government.

Thanks to these ever-growing subsidies, the federations are gradually becoming increasingly professional. Most have professional staff, even if this is often currently a small administration department with a manager and just two or three employees. Some federations, for example the ski and football federations, are more professional, with around 50 paid staff and budgets of CHF 40 million and CHF 60 million, respectively. Around 60 per cent of sport federations have sponsors, but the contribution of sponsorship to their budgets is small (less than 10 per cent) and five sports (football, hockey, tennis ski and athletics) attract 95 per cent of the money provided by sponsors (interview with SO, 2015).

The government provides no specific support for hiring staff, so the movement towards professionalisation has occurred on the initiative of the federations and clubs, with added incentives coming from the performance contracts signed with Swiss Olympic. This analysis illustrates that the system is very different to that in France, where the national coaches are mostly civil servants employed by the sports ministry. In Switzerland, coaches working for a federation are paid directly by that federation, but state-qualified youth and sport coaches working within clubs are paid a salary or an allowance by the Youth + Sport programme.

\section{Performance Measures}

Federations have to report to their members during an annual general meeting, where clubs or their representatives can use their votes to sanction poor sporting and/or financial results. In Switzerland, there are no external public audits by private organisations; however, financial audits are mandatory for federations with turnovers of more than CHF 20 million and employing at least 50 staff. Swiss Olympic is the only supervisor that can have a direct impact on a federation by, for example, refusing to release a proportion of the federation's subsidy if the federation fails to provide accounts and/or an annual report. Poor management can also result in a federation losing its subsidy, but this type of sanction is very rare.

\section{Conclusion}

\subsection{Cross-National Comparisons}

This chapter describes and analyses the principal-agent relationship between sports (con)federations and the government body responsible for sport in Switzerland. This relationship is the consequence of the way sport is structured and steered (the legislative and policy framework) and the support (financial, governance, managerial) sports (con)federations receive from the government. Moreover, due to its federal structure and the autonomy of the sport system, Switzerland has no national approach to overall sport policy. Consequently, Swiss sport operates according to a liberal model that leaves room for individual and collective initiatives by members of the sports movement, although there is currently increasing government involvement in sports policy. With respect to the configurations described by Vocasport (2004), Switzerland's organisational model appears to be a hybrid and atypi$\mathrm{cal}$ of the situation in Europe. Given the amount of public investment, both direct and, most importantly, indirect (through th lottery), and the system's entrepreneurial dimension, it can be characterised as an evolving missionary model. This model could be consider similar to the German model, given Switzerland's federal structure, but there are major differences between the two systems, especially with respect to the management of elite sport, which is more centralised, state-supervised and professional in Germany. A 2011 report on elite sport in Switzerland found, for example, that only 30 per cent of Swiss athletes were truly professional, thereby showing that Switzerland lags behind most other western countries (Kempf et al. 2014). 


\subsection{Evolution/Perspectives}

Switzerland has a federal system of government, meaning that there are a lot of partners involved in reaching agreements. Such systems are potentially very inefficient, as partners have different roles and it is not always easy for them to coordinate. However, it has the advantage that once a project has been decided on, the finance usually follows. Having a centralised policy is much less important in the case of 'Sport for All' than it is for elite sport.

In fact, Switzetland lacks an overall strategy for elite sport, raising fears among experts (Kempf, Weber, \& Re, 2014) of a fall in the country's sporting results in major national competitions due to increased international competition (Shibli, De Bosscher, van Bottenburg, \& Bingham, 2012). Consequently, since the end of 2015, Swiss Olympic has been trying to negotiate an extra CHF 30 million to maintain Switzerland's current standing in international sport. This extra money-CHF 15 million from the government and CHF 15 million from the lottery (through a negotiation with the canton; source: interview with a manager of Swiss Olympic)-would enable Swiss Olympic to improve the socio-economic standing of athletes, who receive very little support (a maximum of CHF 18,000 or CHF 20,000 to help best athletes in non-professional sports cover travel, equipment and training expenses) and very little prize money, even from major competitions (maximum of $\mathrm{CHF}$ 40,000 for an Olympic gold medal; source Swiss Olympic).

A final point concerns the fragility of the way Swiss sport is organised, which is based mostly on volunteers, even in the field of top-flight coaching. Although professionalisation is spreading at the national level, the picture at the regional and cantonal levels is more mixed due to a more professional coaching and administrators, except in the largest federations (especially with regard to football, skiing and gymnastics). Consequently, sport federations tend to focus on their core role (organising official competitions at all levels and optimising the results of their national teams). Most of them find it very difficult, if not impossible, to diversify their activities (leisure sport, health through sport, social inclusion through sport, organising 'Sport for All' events, etc.); therefore, they are often unable to work towards the five strategic objectives set by the government in 2000 (especially those relating to the economy, health and sustainable development).

\section{References}

Antidoping. (2014). Retrieved from Antidoping, http://www.antidoping.ch/de

Chappelet, J.-L., \& Mrkonjic, M. (2011). Politique sportive and conjoncture en Suisse. In N. Soguel (Ed.), Des politiques au chevet de la conjoncture = Die Politiken als Retterinnen der Konjunktur, Contributions à l'action publique (pp. 127-147). Lausanne: PPUR.

European Commission. (2014). Special Eurobarometer 412: Sport and physical activity. Report.

Eurostrategies. (2011). Study on the funding of grassroots sports in the EU: With a focus on the internal market aspects concerning legislative frameworks and systems of financing.

Henry, I., \& Ko, L. (2009). European models of sport: Governance, organisational change and sports policy in the EU. In K. Petry \& W. Tokarski (Eds.), Handbuch sportpolitik. Berlin: Hofmann-Verlag..

Kempf, H., Weber, A., \& Re, A. (2014). Elite sport in Switzerland. Swiss Federal Office of Sport (OFSPO).

L'OFSPO. (2016). Retrieved from Office fédéral du sporr OFSPO, http://www. baspo.admin.ch/internet/baspo/fr/home/das_baspo.html.

Lamprecht, M., Fischer, A., \& Stamm, H. (2008). Activité and consommation sportives de la population suisse, OFSPO. http://www.sportobs.ch/fileadmin/ sportobs-dateien/Downloads/Sport_Schweiz_2014_f.pdf.

Lamprecht, M., Fischer, A., \& Stamm, H. (2011a). Clubs sportifs en Suisse. OFSPO, SSUP, Suva, Swiss Olympic. http://www.baspo.admin.ch/internet/ baspo/fr/home/dokumentation.parsys.000183. downloadList. 2706 . DownloadFile.tmp/clubssportifsensuisseetudesurlesportorganise.pdf.

Lamprecht, M., Fischer, A., \& Stamm, H. (2011b). Sport and économie en Suisse. De limportance économique du sport en Suisse. OFSPO.

Lamprecht, M., Fischer, A., \& Stamm H.. (2014). Sport Suisse. Activité and consommation sportives de la population suisse. OFSPO, SSUP, Suva, Swiss Olympic. htrp://www.baspo.admin.ch/internet/baspo/fr/home/aktuell/ Sport_Schweiz_2014.html.

Rutter \& Partner. (2013). Economic importance of international sport organizations in Switzerland. hrtp://ruetter-soceco.ch/cm/en/project/sport-and-cultureand-events/viewcategory/920-economic-importance-ofinternational-sports-organizations-in-switzerland.

Shibli, S., De Bosscher, V., van Bottenburg, M., \& Bingham, J. (2012). Forecasting the performance of nations in elite sport. In L. Robinson, 
- P. Chelladurai, G. Baudet, \& P. Downward (Eds.), Routledge handbook of sport management (pp. 86-100). Oxon, UK: Routledge.

Stamm, H., Fischer, A., Nagel, S., \& Lamprecht, M. (2015). Sport clubs in Switzerland. In B. C. et al. (Eds.), Sport clubs in Europe-A cross-national comparative perspective (pp. 401-417). Switzerland: Springer.

Swiss Olympic. (2016). Retrieved from Swiss Olympic, http://www.swissolympic.ch/fr/Qui-sommes-nous/Organisation/Swiss-Olympic-1-Associationfâ̂tière-du-sport-suisse.

Swiss Statistics. (2015) http://www.bls.admin.ch/bfs/portal/en/index.html.

Vocasport. (2004). Vocational education and training in the field of sport in the European Union: Situation, trends and outlook. http://eose.org/wp-content/ uploads/2014/03/vocasport-Final-Report-English-Version.pdf 
ichly informative and theoretically robust comparative study of one of the malon but long lected relationships in contemporary sport policy." arrie Houllhan, Loughborough University, UK

is book will assist academics, students and practitioners to understand the intricacies of the ersections between public policy and governance within sport." ussel Hoye, La Trobe University, Australia

is will become a definitive volume in the field of sport governance and spoit managumitent" legfried Nagel, University of Bern, Switzerland

book explores the organisation and structure of sport in and beyond furope Dramigg unon to-date data, the collection's main focus lies on the relationship between public spont bollo. ctures and sport (con)federations. The authors present thirteen country specific contexts rein sport policy systems are embedded. This evidence provides in-depth descriplioris and lyses within a solid academic and theoretical framework. This volume will be of interest to fents and scholars of Sociology of Sport, Sport Management and Sport Policy.

pen Scheerder is Associate Professor in the Department of Kinesiology and Heact of the cy in Sports and Physical Activity Research Group at the University of Leuven, Belgium! ween 2014 and 2016 he was President of the European Association for Sociology of tE (EASS).

fick Willem is Associate Professor in Sport Management in the Department of Movement Sport Sciences at Ghent University, Belgium, and holder of the Olympic Chair Henricte let Latour-jacques Rogge. She is Academic Coordinator of the Belgian Olympic Academ

n Claes is Scientific Researcher within the Policy in Sports and Physical Activity Research up at the University of Leuven, Belgium. She is involved in research projects on sport policy sport management

\section{algrave tacmillan}

30
00
300
30
$\frac{0}{0} \frac{10}{10}$

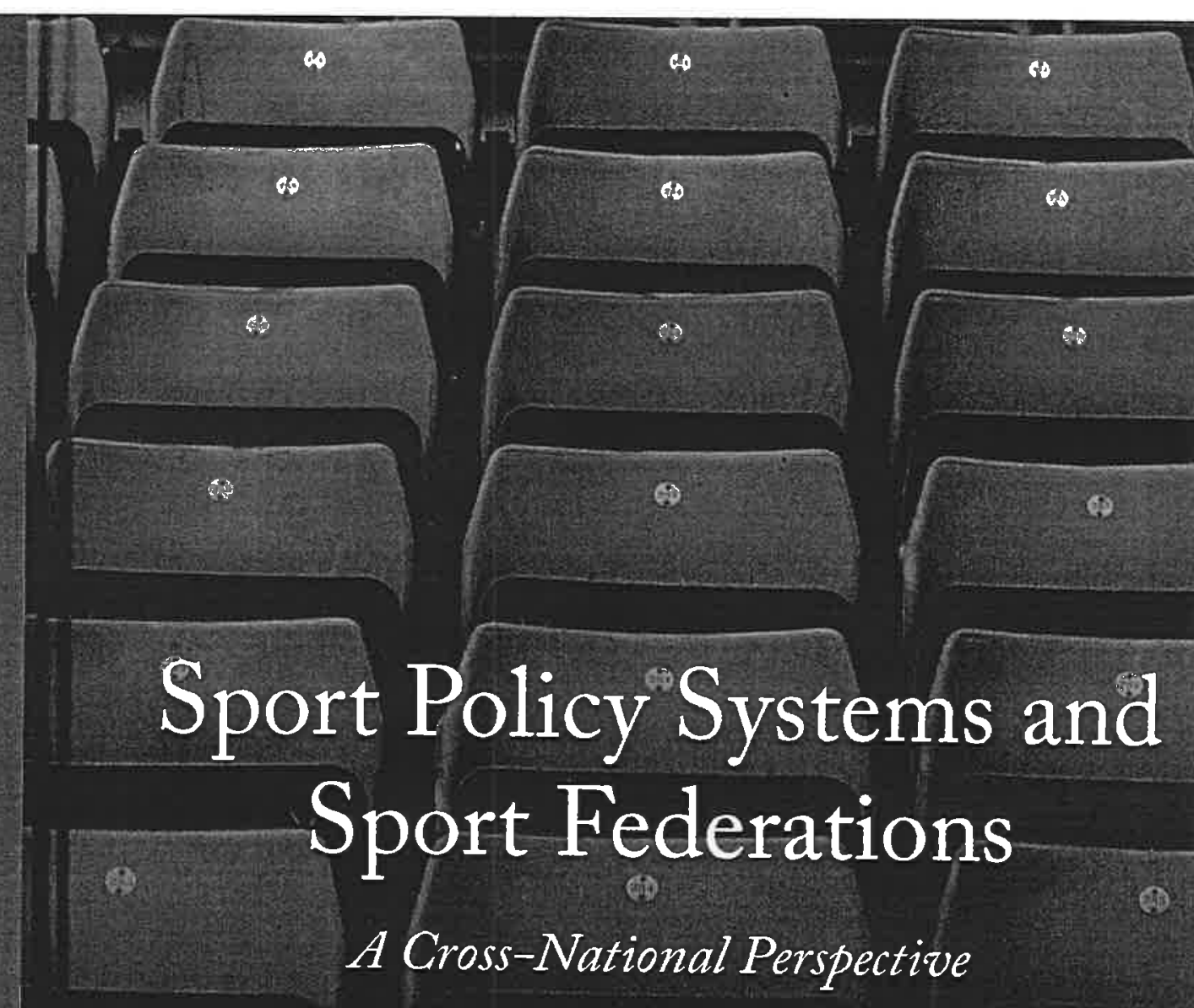

Edited by

Jeroen Scheerder Annick Willem

Elien Claes

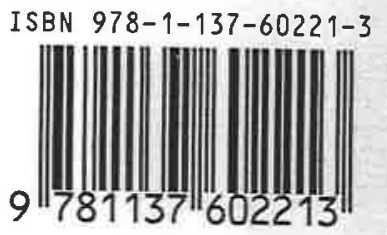

mumpalgravec cor 